\title{
DIE NUWE VERPLEEGONDERWYSSTELSEL: IMPLIKASIES
}

\section{INLEIDING}

In 1982 is aangekondig dat die owerhede goedgekeur het dat verpleegkolleges by universiteite kan affilieer. Verpleegkundiges is nog onseker oor die nuwe stelsel en onderhoude is gevoer met Iris Röscher en Odelia Müller om antwoorde te kry op sommige van die vrae.

Dit het geblyk dat die implikasies verreikend is aangesien die affiliasiebeginsel met breëre vernuwing in verpleegonderwys gepaard gaan.

Mej Iris Rōscher en Mej Odelia Mūller was albei nou betrokke by dit wat die aankondiging dat verpleegkolleges aan universiteite kan affilieer voorafgegaan het. Hulle het ook 'n belangrike uitvoerende rol in die implementeringsfase. Mej. Rôscher is Direkteur (Verpleegdienste) van die Departement van Gesondheid en Welsyn en ook President van die Suid-Afrikaanse Raad op Verpleging. Mej Müller is Adjunk-Direkteur (Verpleegdienste) by dieselfde Departement, Vise-president van die SuidAfrikaanse Verpleegstersvereniging en dien ook op die Suid-Afrikaanse Raad op Verpleging. Albei is lede van die Sub-komitee oor Verpleging en Mej Müller was sameroeper van 'n komitee wat 'n in-diepte ondersoek oor die verpleegonderwysstelsel in Suid-Afrika gedoen het.
Dit is noodsaaklik omdat verpleegonderwys volwaardig deel moet word van die land se na-sekondêre onderwysstelsel en sekere knelpunte derhalwe uit die weg geruim moet word.

Elke verpleegkundige is medeverantwoordelik om dié nuwe ontwikkeling te laat slaag en wanbegrippe en negatiewe houdings moet voorkom word deur vertroud te raak met die feite. Elkeen moet oortuig wees dat die verandering noodsaaklik is vir die beroep om tred te hou met die eise van die moderne samelewing.

\section{DIE HUIDIGE EN DIE NUWE STELSELS}

Hoekom voldoen die huidige stelsel nie aan die eise van moderne verpleegonderwys nie?

Die verpleegonderwysstelsel in Suid-Afrika het, soos ook in baie ander lande, so ontwikkel dat die student deur die hospitaal in diens geneem word en opleiding aan haar voorsien word om in die eerste plek in die hospitaal se behoeftes aan pasiëntsorg te voorsien. Sy het oor die jare byna uitsluitlik werkkrag geword.
Opleidingshospitale, en nie kolleges nie, word deur die SA Raad op Verpleging as opleidingskole goedgekeur, en alle kommunikasie oor opleiding met of van die Raad vind via die hospitaal plaas. Die skool of kollege wat vir die aanbieding van die teoretiese deel van die kursus verantwoordelik is, is 'n lokaal vir teoretiese onderrig en eksamens, wat aan die dienste gekoppel is. Hospitale as sulks is nie nasekondêre onderwysinstansies nie en met die huidige stelsel kan daar nooit in werwingsaksies met ander gevestigde na-sekondêre onderwysinstellings meegeding word nie.

Onder gedelegeerde gesag van die hospitaalsuperintendent is die hoofverpleegdiensbestuurder in beheer van opleiding. Omdat pasiëntsorg die verpleegdiensbestuurder se eerste prioriteit is, en móét wees, word die onderwysbelange van die student noodwendig tweede gestel.

Die aard van die huidige stelsel bring dus mee dat verpleegonderwys nie die erkenning as volwaardige na-sekondêre onderwys geniet wat dit verdien nie en dat die student se totale leerbehoeftes nie altyd bevredig word nie, omdat diensbehoeftes prioriteit geniet. 
Hoe gaan verpleegonderwys verander onder die nuwe stelsel?

Saam met die implementering van die affiliasie-beginsel is hernuwing en herorganisasie in verpleegonderwys nodig sodat dit kan voldoen aan die eise van moderne hoër onderwys.

Die milieu moet gerig wees op onderrig met groter klem op die verpleegstudent as professionele persoon in wording. Daar moet minder op haar as werkkrag gesteun word.

Die nuwe stelsel sal verpleegonderwys meer kompeterend met dié van ander beroepe maak en hopelik ook bydra tot groter beroepstrots en -status.

\section{DIE IMPLIKASIES VAN DIE NUWE STELSEL}

\section{Kolleges}

Hoe gaan die aard van kolleges verander?

Vandag is die verpleegkollege deel van en ondergeskik aan die dienssituasie en die hoofverpleegdiensbestuurder is, onder gedelegeerde gesag, oorhoofs in beheer van die kollege.

Onder die nuwe stelsel gaan die kolleges selfstandig wees. Dit impliseer nie noodwendig selfstandigheid of onafhanklikheid in ' $n$ fisiese sin nie, maar wel dat die kollege apart van die hospitaal beheer en administreer sal word. Die kollege sal byvoorbeeld oor 'n eie begroting, diensstaat en administratiewe afdeling beskik, maar fasiliteite soos studentverblyf en etes kan nog deur die hospitaal voorsien word.

Die aktiwiteite van die onafhanklike kollege wat by 'n universiteit geaffilieer is sal deur 'n oorkoepelende kollegeraad beheer en gerig word. Op aanbeveling van die SubKomitee oor Verpleging het die $\mathrm{Na}$ sionale Gesondheidsbeleidsraad (NGB) beleid neergelê oor die samestelling van dié Raad. Die kollege, universiteit en die dienste wat praktikafasiliteite voorsien, sal onder andere daarop verteenwoordig wees.

Die kollege sal by die Suid-
Afrikaanse Raad op Verpleging aansoek moet doen om goedkeuring as opleidingskool. Die Raad beoog om minimum vereistes vir kolleges te stel en sal hulle ook inspekteer om te verseker dat minimumstandaarde gehandhaaf word.

Ho e w e l s t u d e n t e vir praktikadoeleindes nog in poste as studentverpleegkundiges by die hospitaal aangestel gaan word, sal hulle by die kollege as studente inskryf. Die kollege sal dus meer betrokke raak by keuring en aanstelling van studente as wat vandag die geval is.

'n Volledige ondersteuningstelsel vir die student moet ook deur kolleges voorsien word. Dit sluit onder andere die gewone onderrig-fasiliteite, 'n administratiewe onderbou, studenteberaad en ontspanningsgeriewe in. Die kollegehoof, en nie die verpleegdiensbestuurder nie, sal dus oorhoofs vir die uitvoering van die totale onderwysprogram verantwoordelik wees.

Gaan alle professionele verpleegonderwys voortaan by onafhanklike kolleges aangebied word?

Dit word in die vooruitsig gestel dat alle basiese kursusse vir registrasie by onafhanklike, geaffilieerde kolleges aangebied sal word. Owerhede het goedgekeur dat die nuwe stelsel vir alle bevolkingsgroepe sal geld. Geografiese ligging van kolleges en universiteite sal een van die bepalende faktore vir affiliasie wees.

Na-registrasie kursusse waarin Raadseksamens tans afgeneem word sal ook by die kolleges aangebied word. Fasiliteite by die kolleges kan benut word vir die subprofessionele kursusse vir inskrywing maar dié kursusse sal nie in samewerking met universiteite aangebied word nie.

\section{Universiteite}

Wat sal die rol van die universiteit waarby die kollege geaffilieer is wees?

Die universiteit waarby die kollege geaffilieer is, sal in die kollegeraad verteenwoordig wees. Op hierdie vlak sal die Universiteit dus be- trokke wees in besluitneming oor die totale onderwysprogram wat aspekte soos finansies, bepaling van fasiliteite, die kurrikulum, aard van praktika, kwalifikasies en aanstelling van dosente, en keuring insluit.

Die universiteit sal ook eksterne eksaminator wees vir eksamens wat plaaslik deur die kollege afgeneem gaan word. Die SA Raad op Verpleging se nasionale eksamens vir registrasie as verpleegkundige gaan dus mettertyd heeltemal uitgeskakel word.

Die Raad vereis dat die universiteit waarby ' $n$ kollege affilieer oor 'n departement verpleegkunde moet beskik. Dit word voorsien dat daar ook op 'n breër vlak as die kollegeraad skakeling tussen verpleegdosente van die universiteit en die kollege sal wees en selfs net hierdie wedersydse skouerskuur behoort verpleegonderwys positief te beïnvloed.

Sal universiteitsfasiliteite aan kolleges beskikbaar gestel word?

Verpleegkolleges moet ontwikkel word as volwaardige onderwysinstellings soortgelyk aan die kolleges waar onderwysers opgelei word. Owerhede moet derhalwe kolleges só ontwikkel dat studente trots is om daar op te lei. Die gedagte is nie dat kolleges deel gaan word van universiteitskampusse nie en die nodige fasiliteite soos biblioteekgeriewe en onderrighulpmiddels moet op die kollegekampus voorsien word.

Afhangend van individuele situasies en omstandighede kan ooreenkomste vir die benutting van universiteitsfasiliteite egter aangegaan word.

Sal universiteite vir hul bydrae vergoed moet word?

Al die finansiële implikasies van die affiliasie is nog nie duidelik nie en sal waarskynlik uit komende samesprekings blyk.

Dit word nie voorsien dat dit vir universiteite noodwendig nodig sal wees om addisionele personeel aan te stel nie. Moontlik sal owerhede reis- en verblyfkoste vir die bywoning van kollegeraadvergaderings 
deur universiteitspersoneel moet betaal waar die afstand tussen die kollege en universiteit groot is.

Sal studentverpleegkundiges universiteitskrediete kry vir sommige vakke?

Onderwysstudente en studente op sekere kursusse aan technikons kry krediet vir sekere vakke wanneer hulle later vir 'n universiteitsgraad inskryf.

Universiteitskrediete word gesien as 'n groot langtermynvoordeel van die affiliasie van verpleegkolleges by universiteite. Die moontlikheid is beslis al bespreek maar geen definitiewe besluite is nog in dié verband geneem nie.

\section{Die Suid-Afrikaanse Raad op Verpleging}

Hoe gaan die $\mathbf{R a a d}$ in die toekoms standaarde verseker?

Hoewel die Raad nie meer nasionale eksamens vir basiese kursusse vir registrasie gaan afneem nie is hy nog volgens Wet die liggaam wat standaarde in verpleegonderwys moet verseker.

Kolleges sal deur die Raad as verpleegonderwysinstansies goedgekeur moet word soos wat in die verlede die geval met opleidingskole was. Sekere minimumvereistes sal aan kolleges gestel word.

Die Raad het 'n nuwe onderwysbeleid geformuleer en 'n nuwe formaat van leergange, wat aanpas by hedendaagse onderwyspraktyk, word reeds ingestel.

Die Raad wil ook die wyse van inspeksies verander om veel groter klem op leidinggewing te plaas en verskeie maatreëls word getref om dit te bewerkstellig. Nuwe evalueringsinstrumente vir inspeksies word reeds getoets en dit word beoog dat meer tyd by kolleges deurgebring sal word. Die Raad se professionele afdeling word ook uitgebrei - twee poste vir professionele beamptes is reeds geskep en dié diensstaat sal waarskynlik in die toekoms groter word.

Die Raad meen ook dat daar knelpunte is in die kommunikasie met kollege- en ander personeel wat sy beleid moet uitvoer. Die onderwyskomitee beplan op die oomblik metodes om beter kommunikasie te bewerkstellig en die professionele beamptes sal waarskynlik hierin ook 'n belangrike rol vertolk. Groter seggenskap van verpleegdosente in onderwysontwikkelings word reeds verkry deur persone uit die veld te koöpteer om in werkkomitees van die onderwyskomitee te dien.

\section{Die Dosent}

\section{Sal poste van dosente opgradeer} word?

Dit sal 'n logiese uitvloeisel van die affiliasie wees maar die struktuur sal deur die Kommissie vir Administrasie bepaal moet word.

Dosente se korttermynverwagtinge moet egter nie te hoog wees nie. Die kwalifikasievereistes wat aan hulle gestel word is nie gelyk aan dié vir lektore by ander hoër onderwysinstansies nie.

\section{Sal hoër kwalifikasies van dosente vereis word?}

As die beroep wil sien dat die verpleegdosent dieselfde status kry as dié in ander na-sekondêre onderwys sal dit mettertyd móét gebeur.

Die Suid-Afrikaanse Raad op Verpleging kan in die toekoms moontlik hoër minimumvereistes stel. Hy neem egter altyd die nasionale situasie in ag en kan nie in die oorgangstydperk eise stel wat onprakties is en implementering kan kniehalter nie. Op die oomblik word vereis dat die persoon in beheer van 'n opleidingskool in verpleegadministrasie en verpleegonderwys geregistreer moet wees. Dit is dus logies dat dieselfde minimumvereiste vir hoofde van kolleges sal geld.

Owerhede gaan dringende aandag skenk aan geleenthede vir dosente om hul kwalifikasies te verbeter soos byvoorbeeld gunstiger studieverlofvoordele.

Gaan die aard van die dosent se werksaamhede verander?

Die nuwe stelsel vereis dat die dosent meer betrokke moet raak by die kliniese praktika van haar studente. Noue skakeling en samewerking tussen die dosent en personeel in die dienste is noodsaaklik om die student se praktika sinvol te beplan en te rig. Hierdie oogmerk hou baie praktiese probleme in, veral waar daar 'n groot afstand is tussen die kollege en die hospitaal of ander diens waar praktika gedoen word.

In Engeland is dosente betreklik mobiel en hulle reis waar nodig om studente in die praktiese situasie op te volg. Iets soortgelyks sal plaaslik oorweeg moet word, maar weens finansiële en maatskaplike implikasies is die oplossing nie eenvoudig nie.

Hoe gaan die dosent paraat gehou word ten opsigte van kliniese praktyk?

Die owerhede is opreg in hul voorneme om die dosent te help om selfvertroue in die praktyk te kry en/of te behou. Dit word beoog om groter voorsiening te maak vir voortgesette onderwysgeleenthede soos saaltoewysing, bywoning van toepaslike simposia en so meer.

Daar is baie moontlikhede en voorstelle uit die beroep sal verwelkom word. Die dosent kan byvoorbeeld vir 'n maand per jaar aan 'n saal toegewys word. Haar spesialisasiegebied en keuse van saal, veral in terme van kommunikasie met die persoon in beheer, sal in ag geneem moet word.

Waar gaan die huidige kliniese dosent inskakel?

Kliniese onderrigpersoneel sal deel wees van die kollege personeelvoorsiening. Dit beteken egter nie dat hulle noodwendig in 'n fisiese sin by die kollege sal werk nie.

\section{Die Verpleegdiensbestuurder}

Wat gaan die rol wees van die verpleegdiensbestuurder wat voorheen in beheer van opleiding was?

Omdat hulle nie meer in beheer gaan wees van opleiding nie, is daar verpleegdiensbestuurders wat meen dat hulle deur die nuwe stelsel benadeel word. Indien hulle egter die 
nuwe ontwikkeling in die regte lig beskou behoort hulle dit te verwelkom aangesien die eise in die verlede onmenslik was.

Daar is van die verpleegdiensbestuurder verwag om 'n spesialis te wees beide in verpleegadministrasie en in verpleegonderwys. Benewens die beheer oor verpleegdienste in die hospitaal moes sy verpleegopleiding rig, op datum bly met nuwe opleidingsregulasies van die Raad, administrasie van die opleiding beheer en studentprobleme hanteer.

Hoewel sy nie meer in beheer van alle aspekte van verpleegonderwys sal wees nie, het die verpleegdiensbestuurder nog 'n belangrike verantwoordelikheid onder die nuwe stelsel.

As lid van die kollegeraad neem sy deel op die vlak van beplanning, koördinasie en evaluering van die totale onderwysprogram. Die verpleegdiensbestuurder sal bepaal hoeveel studente die kollege kan inneem aan die hand van die fasiliteite wat vir kliniese praktika beskikbaar is. Sy sal ook nog verantwoordelik wees vir die student wanneer laasgenoemde as lid van die span kliniese praktika doen.

Verpleegkundiges in die dienste sal, soos altyd in die verlede, studente moet begelei en help om teorie en praktyk te korreleer. Die verpleegdiensbestuurder moet saalpersoneel in hierdie opsig lei en ondersteun en ook help om goeie kommunikasie tussen kollege en saalpersoneel te bewerkstellig.

Onder die nuwe stelsel sal die verpleegdiensbestuurder en die kollegehoof dus elk die geleentheid kry om op hulle eie gebiede te spesialiseer. In verpleegonderwys moet hulle mekaar aanvul en dit sal slegs moontlik wees in 'n klimaat wat deur wedersydse konsultasie en goeie samewerking gekenmerk word.

\section{Die student en haar onderrig}

Hoe gaan die student se posisie beïnvloed word?

Die verpleegstudent kry groter studentstatus deurdat sy by 'n kollege inskryf wat ook haar totale onder- wysprogram rig en 'n ondersteuningstelsel voorsien. Die nuwe stelsel behoort mee te bring dat die klem in die student se studiejare op goeie teoretiese en praktiese onderrig val. Die stelsel van verpleegonderwys word dus soortgelyk aan ander na-sekondêre onderwys.

$\mathrm{Om}$ by hedendaagse neigings in onderwys aan te pas maak die nuwe formaat van leergange van die SuidAfrikaanse Raad op Verpleging voorsiening vir program- en stadiumdoelstellings en ' $n$ voortgesette plaaslike kurrikuleringsprogram. Daar word uitgespel oor watter kennis- en praktiese vaardighede die student op elke stadium van haar onderrig moet beskik en dus ook wat geëvalueer moet word. Die nuwe leergange sal noodwendig meebring dat teoretiese en kliniese onderrig, en die evaluering daarvan, meer doelgerig verloop.

Impliseer die nuwe stelsel dat studente minder kliniese praktika gaan doen?

In verpleegonderwys was teorie en praktyk nog altyd onafskeidbaar omdat die professionele verpleegpraktisyn volle verantwoordelikheid vir haar praktyk moet aanvaar sodra sy kwalifiseer.

Die Suid-Afrikaanse Raad op Verpleging onderskryf, en het aan die owerhede die versekering gegee, dat die Suid-Afrikaanse verpleegkundige altyd 'n vaardige professionele praktisyn sal wees en dat dieselfde hoeveelheid kliniese praktika derhalwe onder die nuwe stelsel vereis gaan word. Die student sal nog by die hospitaal as studentverpleegkundige aangestel word en deel wees van die gesondheidspan wanneer sy kliniese praktika doen.

Die student is egter primêr 'n persoon wat nog gevorm moet word tot professionele praktisyn en daar moet minder op haar as werkkrag gesteun word. Dit impliseer 'n klemverskuiwing in kliniese praktika - dit moet gerig wees op die leerbehoeftes van die student met groter nadruk op onderrig en ontwikkeling. Die SA Raad op Verpleging huldig lank reeds dié siening en dit word nou ook deur die owerhede onderskryf.
Hoe gaan dié klemverskuiwing meegebring word?

Daar is nie ' $n$ eenvoudige resep hiervoor nie. Daar word vir verskeie maatreëls voorsiening gemaak in die beleid en nuwe leergange van die SA Raad op Verpleging asook in die beleidsriglyne wat die NGB op voorstel van die Sub-komitee oor Verpleging aanvaar het. Dit is egter slegs breë riglyne en dit sal nodig wees vir persone in beide verpleegonderwys en -dienste om reg ingestel te wees en skeppend saam te werk om oplossings te vind en die nodige verandering te bewerkstellig.

Daar word byvoorbeeld in die beleidsriglyne van die NGB uitgespel dat alle afdelings in groot opleidingshospitale nie vir kliniese praktika gebruik moet word nie.

Die implikasie hiervan is dat kollegepersoneel en verpleegdiensbestuurders saam moet beplan watter afdelings gebruik sal word en hoe hulle van ander sale gaan verskil. Personeelvoorsiening sal waarskynlik aangepas word en besondere eise aan die saalsuster gestel word. In kliniese praktika sal die saalsuster nog soos in die verlede die belangrikste rolmodel en begeleier van die student wees. Spesiale indiensopleidingskursusse soos in studentevaluering, kan moontlik vir die verpleegkundiges in beheer van die opleidingsale angebied word.

Die SA Raad op Verpleging vereis dat die toewysing van studente aan sale en ten opsigte van spesifieke werksaamhede meer wetenskaplik moet wees. Hierin sal die dosent, verpleegdiensbestuurder en saalsuster ook moet saamwerk. Eerstejaarstudente behoort net aan verpleging van individue blootgestel te word. Soos die student vorder kan sy verantwoordelikheid vir groepe pasiënte in die saal of in gemeenskapsdienste aanvaar.

Bogenoemde sal moontlik wees waar verpleegdienste nou wegbeweeg van funksionele taaktoewysing na pasiënttoewysing en die toepassing van die verpleegprosesbenadering. Wetenskaplik beplande toewysing sal natuurlik makliker wees in 'n groot hospitaal met baie 
studente as in kleiner plattelandse hospitale.

'n Meer wetenskaplike benadering tot evaluering van die student se kliniese vaardighede is ook nodig. Die Suid-Afrikaanse Raad op Verpleging het reeds gevra dat instrumente plaaslik ontwikkel en aan hom voorgelê word. Hy is beïndruk met dit wat reeds gedoen is en oortuig dat verpleegkundiges in die veld wel in staat sal wees om die vernuwings te implementeer.

\section{VORDERING MET IMPLE- MENTERING}

\section{Hoe ver is daar al gevorder met die implementering van die nuwe stelsel van verpleegonderwys?}

Sedert daar in April 1982 aangekondig is dat die beginsel van affiliasie van verpleegkolleges by universiteite goedgekeur is, is riglyne deur die Minister van Nasionale Opvoeding aan universiteite gegee en die NGB het beleid neergelê vir die gesondheidsowerhede.

Die Suid-Afrikaanse Raad op Verpleging tref al 'n geruime tyd lank voorbereidings deur aanpassing van leergange, onderhandelings met owerhede oor verskeie aspekte en die uitbreiding van sy professionele afdeling.

Die aanvoorwerk is dus gedoen. Nou moet owerhede kolleges aanpas sodat hulle onafhanklik kan funksioneer en affiliasieooreenkomste tussen owerhede en universiteite moet aangegaan word.

Dwarsoor die land is behoeftebepaling, beplanning, beraming en bespreking aan die gang. Aspekte wat aandag kry is onder andere 'n ontleding deur elke owerheid van sy opleidings-instellings met die oog op rasionalisering, watter praktikafasiliteite beskikbaar is, logistiek, finansies, uitbreiding van diensstate en die daarstelling van administratiewe afdelings in kolleges.

Op plaaslike vlak moet kollegepersoneel en verpleegdiensbestuurders saam die detail oor veranderings in teoretiese en kliniese onderrig uitwerk.

1983 sal gekenmerk wees deur voorbereiding en gesprekvoering en die eerste affiliasies sal waarskynlik in 1984 plaasvind.

\section{VOOR- EN NADELE}

Wat is die grootste voordele en nadele van die nuwe stelsel?

Die nuwe stelsel hou baie voordele vir die verpleegberoep as geheel in.

Verpleegonderwys word volwaardig deel van die land se nasekondêre onderwysstelsel. Dit behoort verpleegonderwys meer kompeterend te maak met dié vir ander beroepe en sodoende werwing en behoud van studentverpleegkundiges te bevorder. In die langtermyn sal dit die status van die beroep verhoog en aan verpleegkundiges groter selfvertroue en beroepstrots gee. 'n Meer wetenskaplik-geldige onderwysstelsel sal noodwendig ook die gehalte van verpleging positief beïnvloed.

$\mathrm{Na}$ die jarelange stryd vir hierdie vernuwing is dit moeilik om nadele te identifiseer.

Die finansiële implikasies, soos met enige nuwe ontwikkeling, kan moontlik as 'n nadeel beskou word. Al die implikasies is nog nie duidelik nie, maar gelukkig kan finansies vir baie van die aspekte, soos die uitbreiding van diensstate en fasiliteite, oor 'n tydperk van 'n paar jaar voorsien word.

Ander nadele kan slegs deur mense gemaak word as daar weerstand teen die omvattende veranderinge is.

\section{SLOT}

Is daar enige spesifieke boodskap of riglyne vir verpleegkundiges ten opsigte van die implementering van die nuwe stelsel?

\section{Odelia Müller:}

Die implementering vereis omvattende gesprekvoering en saambeplanning tussen almal wat betrokke is. Beginsels is aanvaar en breë beleid is neergelê maar daar is nog baie fynere besonderhede wat uitgewerk moet word.
"Almal in die beroep moet saampraat. Die SA Verpleegstersvereniging was nog altyd dié liggaam wat kommunikasie in die beroep bewerkstellig het en ek sien dat hy in hierdie veranderinge ook ' $n$ belangrike rol in die bevordering van kommunikasie het. Die onderwerp van hierdie jaar se vergadering van die Suid-Afrikaanse Verplegingsforum ${ }^{*}$ is die veranderinge in die verpleegonderwysstelsel. Bespreking op topvlak is dus bewerkstellig en ek hoop dat kommunikasie ook op plaaslike vlak deur streekbesture en takke van die Vereniging bevorder sal word."

\section{Iris Röscher}

1982 was gekenmerk deur die aankondiging van ingrypende veranderinge. In die verkryging van die nuwe bedeling het die verpleegberoep ongekende samewerking van beide die gesondheids- en opvoedkundige owerhede gekry. Dit word veral aan die beroep se geloofwaardigheid in die samelewing toegeskryf.

"Al wat die nuwe bedeling nou kan laat skade ly is as daar negatiewe houdings is, gebaseer op eie gewin of wanbegrippe. Elke verpleegkundige het ' $n$ verantwoordelikheid om die nuwe beleid te laat slaag. Ek weier egter om te glo dat die beroep nie, soos nog altyd in die verlede, dié belangrike beroepsaak met eensgesindheid en toewyding sal aanpak nie.

Daar is nog 'n lang pad voor, vol probleme wat met implementering teëgekom sal word. Die sleutel tot sukses is dat elkeen haar van die feite moet vergewis en oortuig moet wees dat dit die enigste weg is om as professionele groep voort te gaan."

-Die Suid-Afrikaanse Verplegingsforum is ' $n$ staande komitee van die Vereniging waarop die hoofverpleegbeamptes van die Departement van Gesondheid, die Suid-Afrikaanse Weermag en die provinsiale departemente van hospitaaldienste, asook die hoofde van departemente van verpleeg kunde, an universiteite, deen depareegker je aan universiteite, dien. Die forum vergader een maal per jaar om sake van gemeenskaplike en nasionale belang te
bespreek. 